\title{
Un caz rar de fibrolipom gigant al coapsei la copil
}

\author{
Andreea Oltean ${ }^{1}$, Cristina Oana Mărginean², Horea Gozar ${ }^{3}$, Horvath Emoke ${ }^{4}$, \\ Mihaela-Ioana Chinceşan² \\ ${ }^{1}$ Clinica Pediatrie I, Spitalul Clinic Judeţean de Urgenţă Târgu Mureş, România \\ ²Disciplina Pediatrie, Universitatea de Medicină şi Farmacie Târgu Mureş, România \\ ${ }^{3}$ Disciplina Chirurgie si Ortopedie Pediatrică, \\ Universitatea de Medicină şi Farmacie Târgu Mureş, România \\ ${ }^{4}$ Disciplina Anatomie Patologică, Universitatea de Medicină şi Farmacie Târgu Mureş, România
}

\begin{abstract}
REZUMAT
Lipoamele sunt tumori benigne compuse din ţesut adipos, tipic localizate subcutanat, mai frecvent în partea superioară a spatelui, la nivelul umerilor, mâinilor şi feselor. Mai rar, lipoamele pot fi întâlnite în profunzimea coapselor. Majoritatea lipoamelor sunt de dimensiuni mici, cântărind doar câteva grame, diametrul maxim fiind sub $2 \mathrm{~cm}$, însă lipoamele gigante au cel puţin $10 \mathrm{~cm}$ diametru şi minimum $1.000 \mathrm{~g}$. Prezentăm cazul unei paciente de sex feminin, în vârstă de 14 ani, care observă, de aproximativ două luni şi jumătate, apariţia unei formaţiuni tumorale pe faţa anterioară a coapsei stângi, internându-se pentru investigaţii în Clinica Pediatrie I Tîrgu Mureş, Compartiment Hemato-Oncologie, cu suspiciunea de tumoră de părţi moi. Examenul de rezonanţă magnetică (RMN) efectuat a evidenţiat un lipom intramuscular al coapsei stângi, cu dimensiuni maxime de 66/44/125 mm, fiind transferată în Clinica de Chirurgie şi Ortopedie Pediatrică pentru excizie. Examenul histopatologic a evidenţiat aspectul de fibrolipom.
\end{abstract}

Cuvinte cheie: lipom, coapsă, copil

\begin{abstract}
Abrevieri
VSH $=$ viteza de sedimentare a hematiilor

$\mathbf{P C R}=$ Proteina $\mathrm{C}$ reactivă
\end{abstract}

\section{INTRODUCERE}

Lipoamele sunt acumulări de țesut adipos localizate frecvent în porțiunea posterioară a gâtului, la nivelul trunchiului, porțiunea proximală a membrelor, dar se pot dezvolta în toate organele corpului fiind localizate intraabdominal, intramuscular sau subcutanat. Ele apar la 1\% din populație, copiii fiind foarte rar afectați.

Aceste tumori benigne au o creştere lentă, formând mase moi, lobulate, înconjurate de o capsulă fibroasă subțire. Sunt compresibile şi pot suferi o serie de transformări ca: atrofie, calcificare, lichefiere, xantomatoză, care pot complica evoluția lor (1). Volumul lor tinde să crească odată cu creşterea în greutate, dar nu se micşorează la scăderea în greutate. Lipoamele multiple, identice sau izolate pot fi transmise autozomal dominant şi de obicei apar în a treia decada de viață a pacienților cu lipomatoză familială multiplă. Există speculații în ceea ce priveşte o posibilă legătură între un traumatism şi apariția ulterioară a unui lipom $(1,2)$.

Diagnosticul diferențial este furnizat de tomografia computerizată $(\mathrm{CT})$, rezonanța magnetică (RMN), biopsie/imunohistochimie (3). Cea mai frecventă tumoră malignă de părți moi este histiocitomul fibros malign, urmat de liposarcom, care se aseamănă cu lipomul la examenul computer tomograf şi la RMN, fiind cel mai frecvent localizat la nivelul coapsei (4). Rezonanța magnetică cu contrast depistează masa lipomatoasă având semnal caracteristic de intensitate mare a țesutului grăsos, fără tendință de creştere (5).

De obicei, nu este necesar tratamentul lipoamelor decât dacă acestea devin dureroase sau restricți- 
onează motilitatea. Excizia chirurgicală se impune din motive estetice, creştere în dimensiuni sau pentru examen histopatologic, când există suspiciunea unui liposarcom (6). Lipoamele cu creştere rapidă sau dureroase pot fi tratate printr-o varietate de proceduri, de la injectare cu steroizi până la excizie. Rezultatul intervenției şi prognosticul lipoamelor este excelent. Recurența este mai puțin frecventă, dar posibilă în cazul lipoamelor excizate incomplet.

Caracterul posibil malign şi tendința de recurență a lipoamelor sunt motivele pentru care atragem atenția asupra lor.

\section{PREZENTARE DE CAZ}

Prezentăm cazul unei paciente de sex feminin, în vârstă de 14 ani, fără antecedente personale patologice, care observă, de aproximativ două luni şi jumătate, apariția unei formațiuni tumorale pe fața anterioară a coapsei stângi, cu creştere rapidă, fără alte simptome. Pacienta s-a prezentat pentru un consult pediatric ambulatoriu, fiind ulterior internată în Compartimentul de Hemato-Oncologie Pediatrică, cu suspiciunea de tumoră de părți moi. Examenul clinic la internare a evidenţiat o stare generală bună, tegumente normal colorate, vergeturi la nivelul coapselor bilateral, fără adenopatii palpabile sau organomegalie, echilibrată cardiac şi respirator. Evaluarea musculoscheletală a evidențiat o masă palpabilă, mobilă, pe fața anterioară a coapsei stângi, cu minimă sensibilitate la palpare, consistență fermă, cu dimensiuni aproximative de
13/7/8 cm, fără deficit motor (Fig. 1 a,b.). Greutatea corporală actuală este de $62 \mathrm{~kg}$ (din anamneză reiese că greutatea corporală anterior apariției formațiunii tumorale era de aproximativ 60 kg). Fără istoric de febră sau traumatism.

Pacienta a fost investigată din punct de vedere paraclinic şi imagistic. Analizele de laborator au relevat valori normale ale markerilor tumorali nespecifici: feritină, cupru seric, fosfatază alcalină, calciu seric, lactat dehidrogenază, absența sindromului inflamator (VSH, PCR normale), coagulogramă normală, creatin-fosfokinaza normală, hemoleucogramă şi frotiu sangvin periferic normale. Electroliții, glicemia, probele renale, hepatice şi electrocardiografia au fost normale. Ecografia coapsei a evidențiat la nivelul muşchiului vast medial în treimea medie şi distală o arie eliptică, bine delimitată, care deviază structurile vasculare din vecinătate, cu extensie minimă de $12 / 5,5 / 7,4 \mathrm{~cm}$, fără semnal Doppler vascular, cu structură omogenă, care mimează structura țesutului muscular, fără semnal vascular sau calcificări la acest nivel.

Ecografia abdominală şi radiografia toracică nu au evidențiat anomalii. Investigațiile diagnostice au fost completate cu examenul RMN, care a evidențiat: lipom intramuscular localizat profund anterior în treimea mijlocie a coapsei stângi, în muşchiul cvadriceps - vastul medial, posterior venind în contact cu diafiza femurală, bine delimitat, cu fine septe incluse, cu dimensiuni maxime de 66/44/125 $\mathrm{mm}$, fără elemente compresive asupra pachetului vascular femural (Fig. 2 a,b).
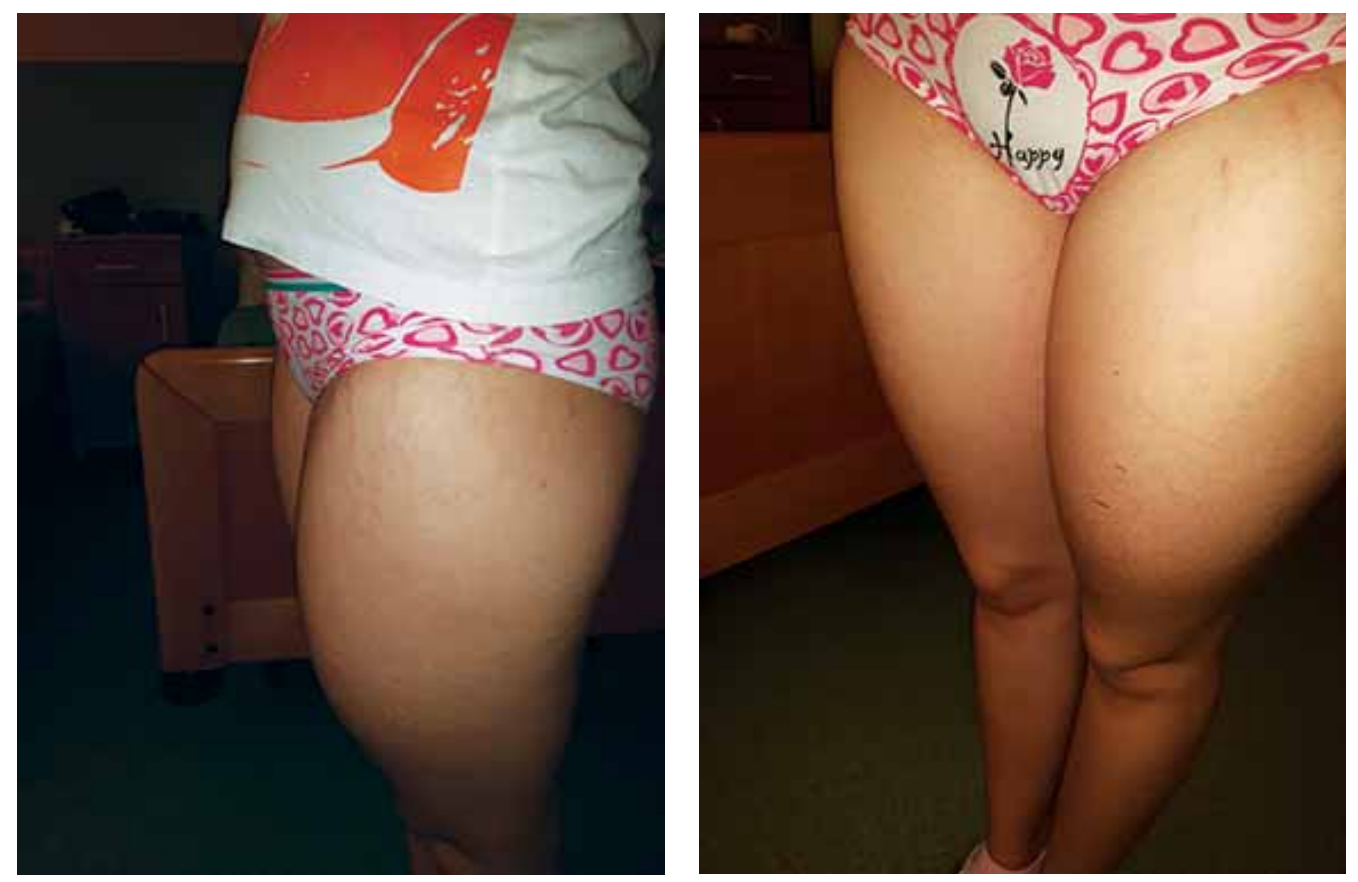

FIGURA 1a şi 1b. Formațiune tumorală pe fața anterioară a coapsei stângi, vergeturi 


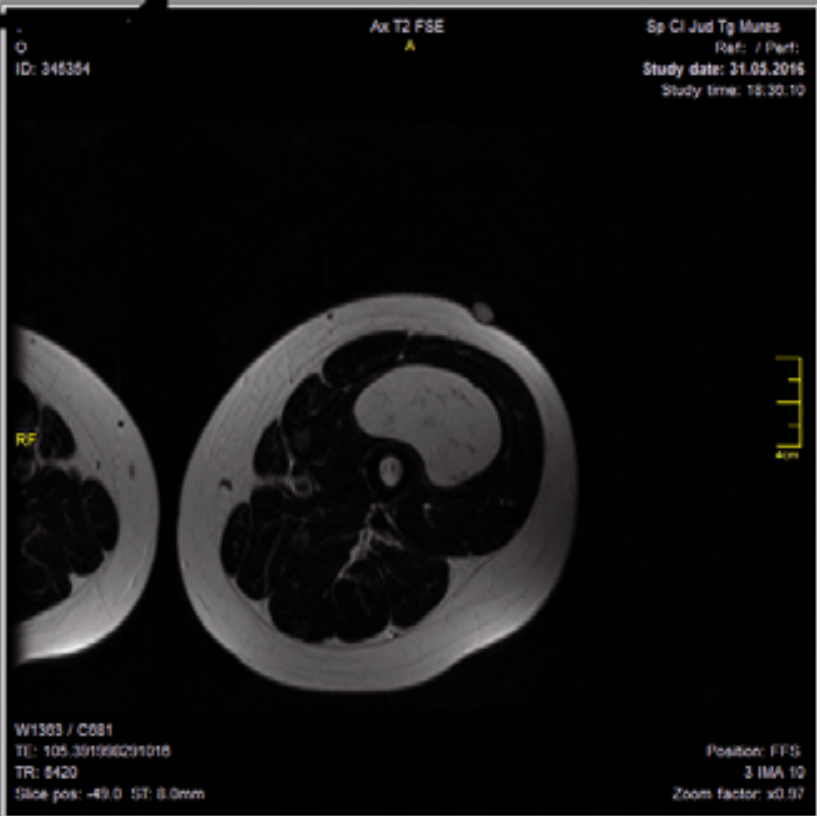

FIGURA 2a. Secțiune axială la nivelul muşchiului vast medial - se observă o formațiune bine delimitată, omogenă cu hipersemnal în T2.

Pacienta a fost ulterior transferată la Clinica de Chirurgie şi Ortopedie Pediatrică pentru excizia completă a lipomului şi examen histopatologic. Descrierea macroscopică a identificat formațiunea tumorală ca fiind din țesut adipos, încapsulată, de consistență elastică, diametrul fiind de 130/60/50 $\mathrm{mm}$, greutatea de $960 \mathrm{~g}$. Descrierea microscopică a evidențiat o formațiune tumorală alcătuită din numeroşi paniculi adipoşi, cu celule mature, fără atipii, despărțite de benzi de țesut fibros. În jurul septurilor fibroase se observă histiocite (Fig. 3 a,b). La nivel celular proteina S100 este negativă, iar indicele de proliferare Ki-67 este redus. Se observă prezența unui infiltrat inflamator preponderent lim-

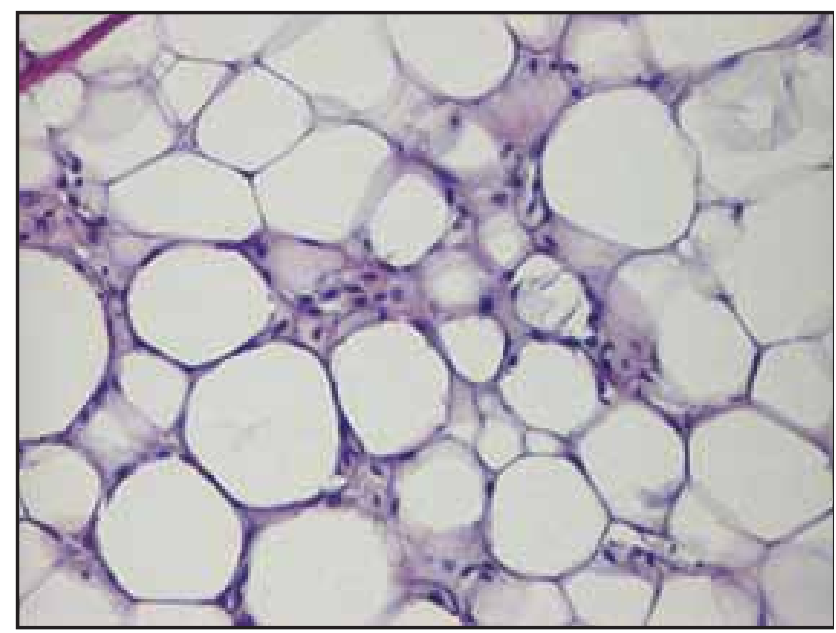

FIGURA 3a. Agregate de celule adipoase mature, fără atipii (colorație hematoxilin-eozină, mărire de 20 x)

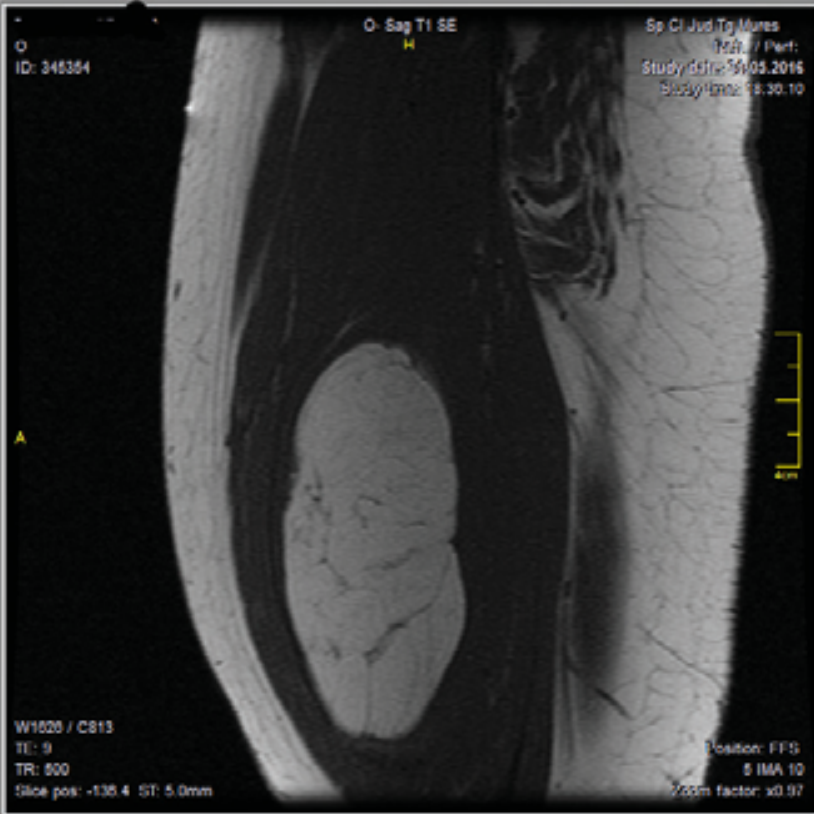

FIGURA 2b. Secțiune sagitală la nivelul muşchiului vast medial - se observă o formațiune ovalară omogenă, bine delimitată, cu fine septe incluse, cu hipersemnal în T1.

focitar. Concluzia examenului histopatologic: fibrolipom complet excizat.

\section{DISCUTुII}

Lipoamele sunt tumori benigne de părți moi, superficiale sau profunde, clinic asimptomatice, dar în unele cazuri pot ajunge la dimensiuni considerabile (7). În cazul prezentat, lipomul a fost asimptomatic, iar volumul său gigant a fost asociat cu creşterea în greutate a pacientei, vizibilă de asemenea prin prezența vergeturilor.

Terzioglu et al. descriu lipoamele de 10/5/3 cm sau de dimensiuni mai mari ca fiind lipoame gigan-

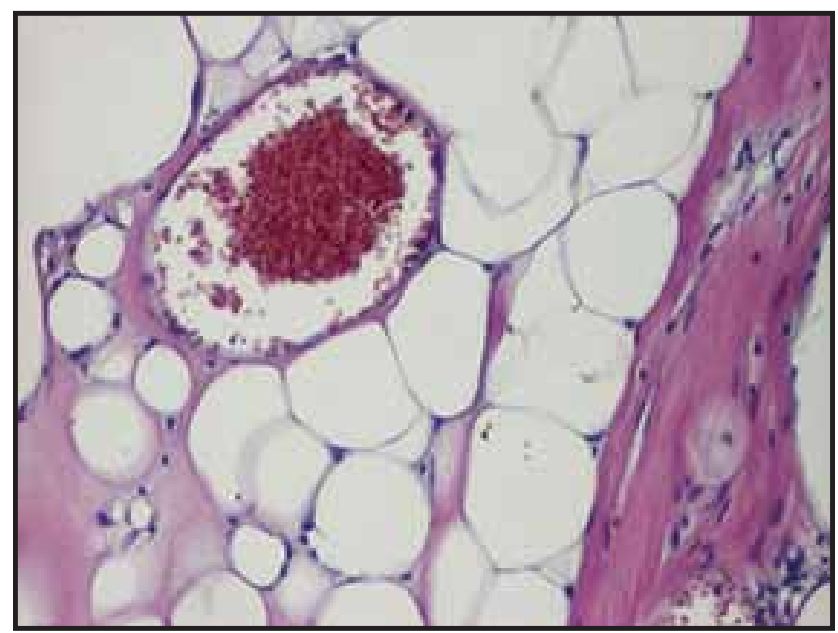

FIGURA 3b. Benzi de țesut fibros şi histiocite (colorație hematoxilin-eozină, mărire de 20 x) 
te şi notează faptul că diagnosticul diferențial al tumorilor de această dimensiune ar trebui să includă şi liposarcomul (8). La prezentul caz expus, măsurătorile lipomului prin rezonanță magnetică au indicat dimensiuni mai mari $(6,6 / 4,4 / 12,5 \mathrm{~cm})$, care au ajutat atât la încadrarea în această categorie, cât şi la diagnosticul diferențial.

Ecografia este investigația imagistică de primă intenţie, datorită costului scăzut şi a disponibilităţii în comparație cu RMN-ul, în evaluarea inițială a tumorilor de părți moi a căror natură nu este pe deplin înțeleasă (9). În cazul prezentat, ecografia nu a permis definirea exactă a leziunii, aceasta fiind fără semnal Doppler. Deşi ecografia nu a putut diferenția între o leziune benignă şi o leziune malignă de grad mic, diagnosticul de lipom gigant a fost completat prin efectuarea RMN-ului, confirmat apoi de examenul histopatologic.

Datorită contrastului tisular excelent şi a lipsei radiațiilor ionizante, rezonanța magnetică a devenit investigația de alegere la copii, în evaluarea maselor de țesuturi moi, profunde şi de dimensiuni mari, definind extinderea acestora şi relația cu structurile adiacente, cât şi în urmărirea postterapeutică (10).

Evaluarea meticuloasă a marginilor şi a caracteristicilor interne la examenul RMN pot fi de ajutor în diferenţierea dintre lipom şi liposarcomul bine diferențiat $(10,11)$. Examinarea RMN în cazul prezentat a arătat nu numai dimensiunile lipomului, dar şi localizarea intramusculară profundă, buna delimitare, cu septuri fine şi absența compresiei pe pachetul vascular femural.

Bjerregaard et al. au arătat în studiul lor faptul că este esențială confirmarea diagnosticului de lipom prin biopsie excizională, deşi examinarea CT preoperatorie este foarte utilă (12). Examinarea histopatologică în cazul de față a descris un fibrolipom gigant complet excizat.

Serpell et al. au concluzionat că indicaţiile de excizie ale lipomului includ: o dimensiune mai mare de $5 \mathrm{~cm}$, localizarea subfascială, o tumoră în creştere, clinic - durere, fermitate, iregularitate sau un rezultat echivoc la biopsia preoperatorie $\mathrm{cu}$ ac fin, dar şi motivele cosmetice (13). Lipoamele mici pot fi îndepărtate prin enucleere. Lipoamele mari sunt îndepărtate prin efectuarea unei incizii în tegumentul ce acoperă lipomul (14).Tratamentul lipomului în cazul prezentat a constat în excizia completă din cauza creşterii rapide în dimensiuni, din motive estetice, dar şi pentru efectuarea examenului histopatologic în vederea precizării diagnosticului pozitiv.

Fibrolipoamele sunt foarte rare la pacienții pediatrici, literatura descrie un caz de fibrolipom congenital la nivelul membrului inferior stâng la un copil de 4 ani, care a fost complet excizat (15). Totuşi, există un risc de recurență după o perioadă variabilă de timp, în ciuda rezecției totale. Aceasta poate să apară ca o transformare malignă.

\section{CONCLUZII}

Lipoamele sunt tumori benigne de țesuturi moi şi trebuie întotdeauna luate în considerare în diagnosticul diferențial al formațiunilor tumorale de la nivelul coapsei. Sunt importante atât recunoaşterea semnelor clinice ale lipoamelor superficiale şi profunde, cât şi identificarea caracteristicilor imagistice ale acestora pentru optimizarea diagnosticului iniţial şi a tratamentului. Ecografia este utilă în evaluarea iniţială a leziunilor mici, superficiale sau când istoricul sugerează un anumit diagnostic, însă, în cazul unui lipom gigant, nu poate diferenția între o leziune benignă şi una malignă. Rezonanța magnetică este frecvent necesară în evaluarea lipoamelor, mai ales în cazul celor profunde şi de dimensiuni mari în care ecografia nu permite definirea exactă a leziunii. Tratamentul lipoamelor constă în excizia completă, însă recurența este posibilă, de aceea urmărirea pe termen lung a acestor pacienţi este necesară ca o măsură de precauție.

Conflict of interest: none declared Financial support: none declared 